\title{
Development and Implementation of Performance Evaluation System for a Water Treatment Plant: Case Study of Taipei Water Treatment Plant
}

\author{
E.-E. Chang ${ }^{1}$; Peng-Chi Chiang ${ }^{2}$; Shu-Mei Huang ${ }^{3}$; and Yi-Li Lin ${ }^{4}$
}

\begin{abstract}
To implement performance assessment, it is necessary to develop adequate and representative performance indicators. Good performance indicators can specify the measurable evidence that is necessary to document the achievement of a goal. To provide the higher quality and stable water to the customers, the water utilities themselves should establish the proper maintenance and management programs to enhance the availability of plant facilities and equipments in the water treatment plant. With the appropriate performance indicators, the objectives and/or targets of the business plan can be evaluated quantitatively. The aim of this research work is to set up the performance evaluation system for the Taipei water treatment plant. After the establishment of performance indicators (seven in this research), the corresponding evaluation items and their relative weights were revealed throughout forum discussion and questionnaire survey and based on the comprehensive performance evaluation technique and analytic hierarchy process method, respectively. Meanwhile, according to the results of performance evaluation and simulation studies by the developed model, an implementation plan for upgrading the performance of the Taipei water treatment plant was proposed, with two important items: (1) proper adjustment of the water production rate, PAC dosage, and sludge management for different turbidities in source water based on the required finished water quality can minimize the total treatment cost and enhance the performance of the water treatment plant; and (2) establishing a regular performance evaluation system to identify potential and existing problems so that correction action could be immediately taken. Developing a sound database program, and cooperating with the stakeholders for source water protection are the major tasks that should be implemented to achieve the objectives of safe drinking water and clean water.
\end{abstract}

DOI: 10.1061/(ASCE)1090-025X(2007)11:1(36)

CE Database subject headings: Performance characteristics; Implementation.

\section{Introduction}

The concept of performance assessment has been in existence for decades. For example, "measuring municipal activities" was promulgated in 1938 by the International City/County Management Association (ICMA 1999). This concept suggested various types of information that local governments could use to monitor and assess the quality and delivery of local services. To implement performance assessment, it is necessary to develop adequate and representative performance indicators. Good performance indicators can specify the measurable evidence necessary to document the achievement of goals. They can provide performance ap-

${ }^{1}$ Dept. of Biochemistry, Taipei Medical Univ., $250 \mathrm{Wu}-\mathrm{Hsing}$ Street, Taipei, Taiwan, Republic of China.

${ }^{2}$ Graduate Institute of Environmental Engineering, National Taiwan Univ., 71 Chou-Shan Rd., Taipei, Taiwan, Republic of China.

${ }^{3}$ Graduate Institute of Environmental Engineering, National Taiwan Univ., 71 Chou-Shan Rd., Taipei, Taiwan, Republic of China.

${ }^{4}$ Graduate Institute of Environmental Engineering, National Taiwan Univ., 71 Chou-Shan Rd., Taipei, Taiwan, Republic of China (corresponding author). E-mail: f88541104@ntu.edu.tw

Note. Discussion open until June 1, 2007. Separate discussions must be submitted for individual papers. To extend the closing date by one month, a written request must be filed with the ASCE Managing Editor. The manuscript for this paper was submitted for review and possible publication on March 15, 2006; approved on April 18, 2006. This paper is part of the Practice Periodical of Hazardous, Toxic, and Radioactive Waste Management, Vol. 11, No. 1, January 1, 2007. CASCE, ISSN 1090-025X/2007/1-36-47/\$25.00. praisal standards, supply criteria for the evaluation of resource development, identify valid interventions, and define new organizational purposes. There are two critical uses of performance indicators: (1) to identify what should be accomplished and (2) to provide criteria for determination of success or failure (Kaufman 1988). However, performance assessment is not adapted widely and effectively for enterprises and government-related entities because of the lack of consistent information and experience (Paralez 2001).

The Taipei water treatment plant, which is the major tap water supplier in the Great Taipei Metropolitan Area, provides $2 \times 10^{6} \mathrm{~m}^{3}$ of drinking water per day, serves about $69 \%(3.8$ million users) of the total residents in the area. This plant is a publicly owned facility governed by the water production department in Taipei Water Company, and consists of grit removal, prechlorination, coagulation, sedimentation, filtration, and postchlorination. A sludge treatment process is employed to treat the backwashed wastewater and settled sludge. As a water utility, it must supply high-quality and stable water to their customers so that it can survive under strict competition (TWD 2000). Therefore, appropriate performance indicators must be developed to provide scientific data and a systematic approach to achieve optimum status for the water utility.

Regarding the operation of a water treatment plant managed by the water utility, a standard operating procedure is needed for achieving optimal performance in water quality control, water production, chemical cost reduction, and waste minimization. A proper maintenance program must be established for a water 


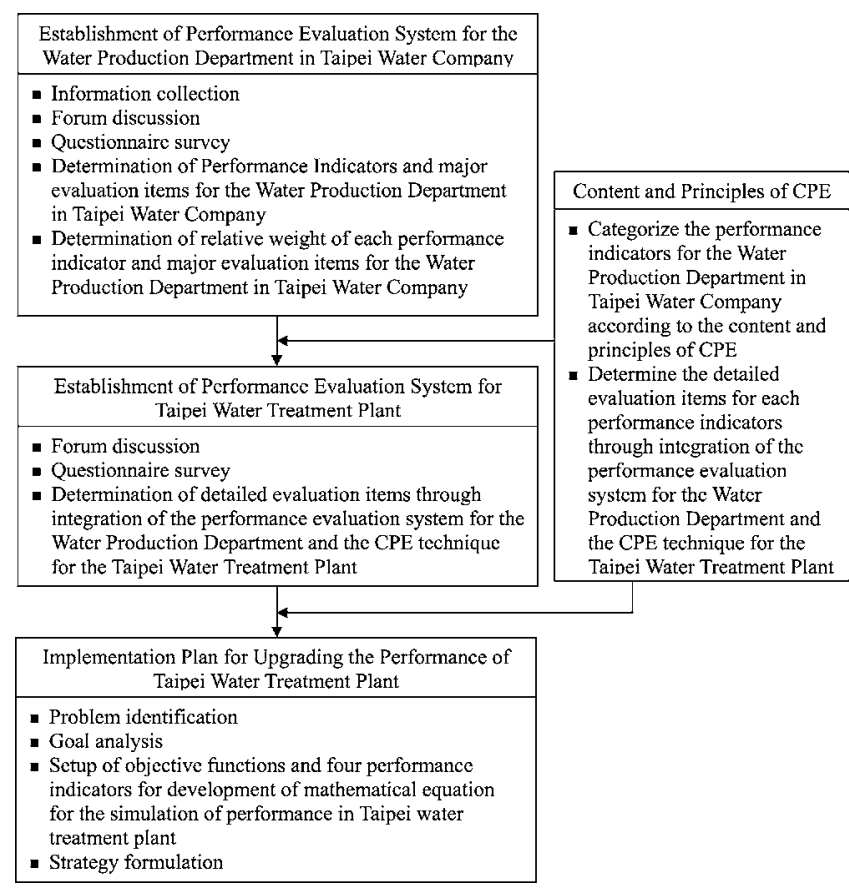

Fig. 1. Schematic diagram of this research

treatment plant to enhance the availability of plant facilities and equipments. A water utility must also have a sound management system thereby providing effective and efficient services for customers. With appropriate performance indicators, its operating performance and goals of achievement can be evaluated quantitatively.

The aim of this research is to set up the performance indicators and their major evaluation items and relative weight associated with each indicator and evaluation items for the Taipei water treatment plant. First of all, the performance evaluation system for the water production department in Taipei Water Company was originally developed through forum discussion, questionnaire survey, and analytic hierarchy process (AHP) method. Second, the performance evaluation system for the Taipei water treatment plant was suggested by the integration of the performance evaluation system for the water production department in the Taipei Water Company and the comprehensive performance evaluation (CPE) technique. The detailed evaluation items and their relative weight associated with each performance indicator were determined based on a CPE technique and AHP method, respectively. Finally, an implementation plan for upgrading the performance of the Taipei water treatment plant was proposed in accordance with the results of performance simulation as well as problem analysis of operation and management information.

\section{Methodology}

The schematic diagram of this research is shown in Fig. 1. There are two steps in the determination of performance indicators. In the first step, performance indicators and their major evaluation items were developed for the water production department in the Taipei Water Company (Fig. 2). In the second step, the developed performance evaluation system from the Water Production Department in conjunction with the CPE technique was introduced to establish the performance evaluation system in the Taipei water

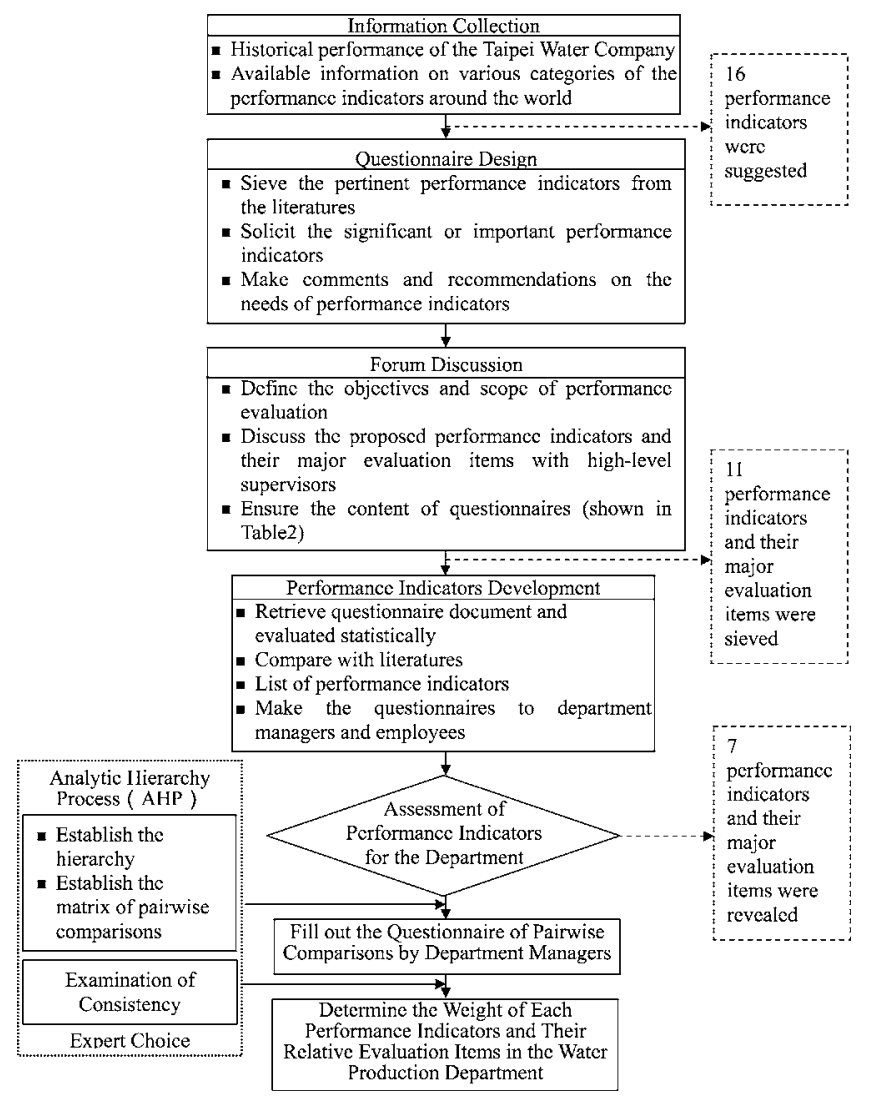

Fig. 2. Flow chart for establishment of performance evaluation system in the water production department in the Taipei Water Company

treatment plant. The detailed description will be shown in the section, "Results and Discussion."

\section{AHP Method}

Developed by Professor Saaty, AHP was used to determine the relative weight value of each performance indicator (Saaty 1980). It simplifies a complicated policy problem by analyzing the structure of each level. The relative weight value of each indicator is determined by comparing pair matrices of standard structures. Results from surveys completed by the experts in this field are also used in this analysis.

In this study, the AHP method was used for the determination of relative weight for each performance indicator and their major evaluation items used for the water production department. A questionnaire in the form of pair comparisons was sent to the managers in the water production department in the Taipei Water Company and managers in the Taipei water treatment plant, respectively. The evaluation scales were divided into five categories-extreme (1 point), very (3 points), somewhat (5 points), slight ( 7 points), and equally important ( 9 points).

After statistical analysis of the retrieved data, it was found that it is difficult to obtain uniform agreement among results in the survey. Therefore, a process to evaluate the uniformity of the results should be conducted. According to Saaty's recommendations, nonuniformity is acceptable if the C.I. (consistency index) value is 0.1 . Since persons filling out the survey form of this 


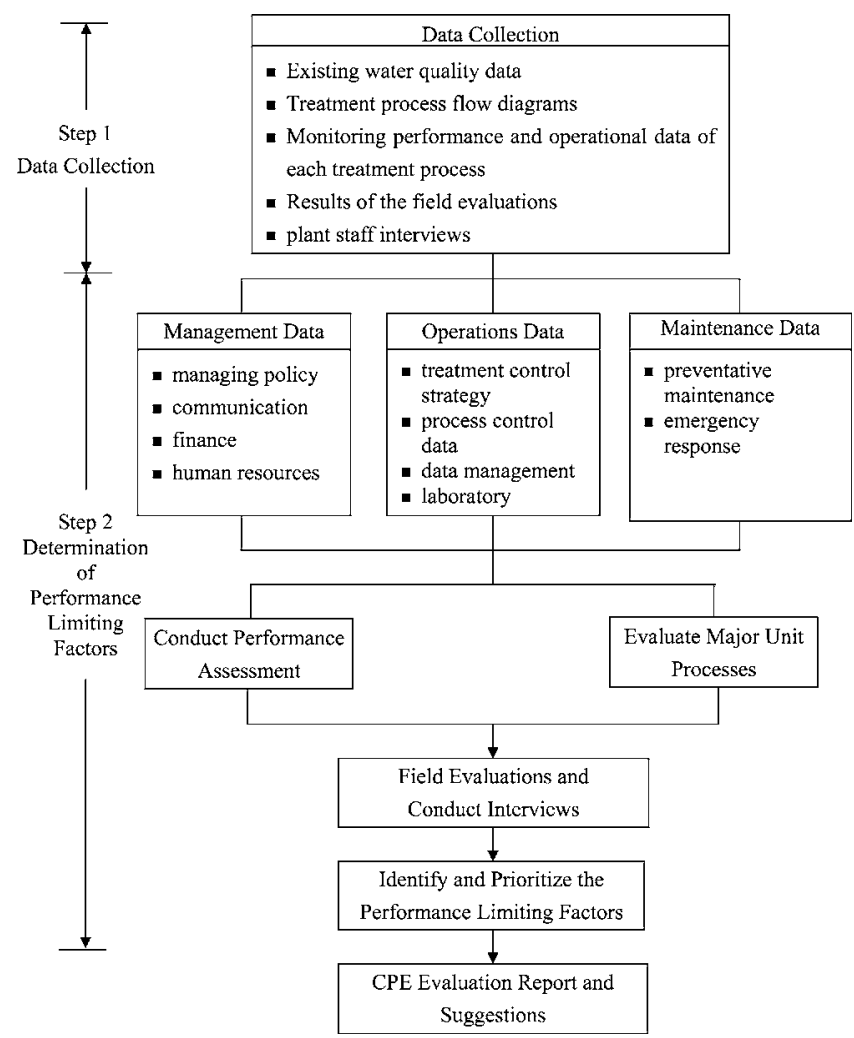

Fig. 3. Flow chart of comprehensive performance evaluation technique

study are not familiar with the level analysis method, the acceptable C.I. value was relaxed to 0.15 . Answer sheets with C.I. values greater than 0.15 were discarded.

\section{CPE Technique}

The CPE technique is a systematic step-by-step process for evaluating the performance of a water treatment plant. It can be used to improve the performance of existing water treatment plants and to achieve optimal performance (USEPA 1998; Choi et al. 2002). There are two steps involved in the CPE technique, i.e., data collection and determination of performance-limiting factors (shown in Fig. 3). After identifying and prioritizing the performance limiting factors, the evaluation reports are proposed by our technical group. The correlations of performance indicators with the management, maintenance, and operation parameters were investigated in this study for the performance indicators in the Taipei water treatment plant.

\section{Results and Discussion}

\section{Establishment of Performance Evaluation System for Water Production Department in Taipei Water Company}

Sixteen performance indicators including water quality control, in-plant modification and contingency plan, water production rate, chemical cost reduction, equipment availability, waste minimization, source water production, electricity consumption, number of employees, reliability of equipments, maintenance of equipments, classification and utilization of maintenance information, inspec- tion and maintenance of facilities, stability of water supply, service of water industry, and drinkable water supply were suggested by our technical advisors based on the available information from the currently performed evaluation indicators in the water production department, operational indicators from industry, financial indicators of city government, and performance indicators used in both context, input, process, and product (CIPP) and western regional water utilities benchmarking group (WRWUBG). The WRWUBG provides lessons with useful insights about "layers" of data that exist in utilities, challenges in using data across those layers, and managing the data toward the goal of performance assessment (Paralez 2001). In this paper, performance indicators are divided into the following four categories: execution; financial; planning and engineering; and operation and maintenance. The framework of CIPP is employed to separate different kinds of performance indicators into four categories: context; input; process; and product. For the balance and integrity of performance assessment, indicators belonging to different categories should be well distributed and represented so that the results of performance assessment can display the effectiveness and efficiency of all processes, not just the "outcome." The correlations between the presieved performance indicators and organization responsibility, business plan, statistical report, and current indicators of Taipei Water Company were evaluated. The characteristics of each performance indicator in the category of CIPP and WRWUBG were also classified.

After discussion with the high-level supervisors in the Taipei Water Company, it suggests that 11 among the presieved 16 performance indicators (shown in the second column in Table 1) may be adequate, but too copious. As a result, the above 11 presieved performance indicators were integrated into a questionnaire and sent to the authorized managers (20 persons) and the representative employees ( 240 persons) in the water production department for further evaluation of these 11 performance indicators. The evaluation scales were divided into five categories as follows: very important (5 points); important (4 points); fair (3 points); less important ( 2 points); and not important (1 points). The contents of the questionnaire utilized in this investigation are shown in Table 2.

The calculated scores for each performance indicator are shown in the column of "questionnaire survey" in Table 1. Based on the practice utilized in the area of organization responsibility, business plan, statistical report, current indicator, CIPP and WRWUBG, and results of the questionnaire survey, the technical advisors recommended seven performance indicators (water quality control, in-plant modification and contingency plan, water production rate, chemical cost reduction, equipment availability, waste minimization, and source water protection) as well as their major evaluation items being used for the water production department (shown in Tables 1 and 2).

In the following, another questionnaire was drawn up in the form of pairwise comparisons for the determination of the relative weight value of each performance indicator and its major evaluation items. This questionnaire was filled out by 15 department managers and then analyzed by the AHP method. Results from the "expert choice" in analyzing the relative weight values of the seven performance indicators are shown in the first column in Table 3. The relative weight values of the major evaluation items are shown in the third column in Table 3. 
Table 1. Comprehensive Review of Performance Indicators Selected for Water Production Department

\begin{tabular}{|c|c|c|c|c|c|c|c|c|c|}
\hline Item & $\begin{array}{l}\text { Performance } \\
\text { indicator }\end{array}$ & $\begin{array}{l}\text { Organization } \\
\text { responsibility }\end{array}$ & $\begin{array}{l}\text { Business } \\
\text { plan }\end{array}$ & $\begin{array}{l}\text { Statistical } \\
\text { report }\end{array}$ & $\begin{array}{l}\text { Current } \\
\text { indicator }\end{array}$ & $\begin{array}{l}\text { Questionnaire } \\
\text { survey }^{\mathrm{a}}\end{array}$ & $\begin{array}{l}\text { Context, } \\
\text { input, } \\
\text { process, } \\
\text { and product }^{\mathrm{b}}\end{array}$ & $\begin{array}{c}\text { Western regional } \\
\text { water utilities } \\
\text { benchmarking } \\
\text { group }^{c}\end{array}$ & $\begin{array}{l}\text { Technical } \\
\text { recommendation }\end{array}$ \\
\hline 1 & Water quality control & $\sqrt{ }$ & $\sqrt{ }$ & & $\sqrt{ }$ & 4.9 & PS & $\mathrm{P} / \mathrm{E}$ & A \\
\hline 2 & $\begin{array}{l}\text { In-plant modification } \\
\text { and contingency plan }\end{array}$ & $\sqrt{ }$ & $\sqrt{ }$ & & $\sqrt{ }$ & 4.7 & PS & $\mathrm{O} / \mathrm{M}$ & A \\
\hline 3 & Water production rate & $\sqrt{ }$ & & $\sqrt{ }$ & & 4.0 & PT & $\mathrm{O} / \mathrm{M}$ & B \\
\hline 4 & Chemical cost reduction & $\sqrt{ }$ & $\sqrt{ }$ & & & 4.2 & PS & $\mathrm{O} / \mathrm{M}$ & B \\
\hline 5 & Equipment availability & $\sqrt{ }$ & & $\sqrt{ }$ & & 4.1 & PT & $\mathrm{O} / \mathrm{M}$ & B \\
\hline 6 & Waste minimization & $\sqrt{ }$ & $\sqrt{ }$ & & & 4.0 & PT & $\mathrm{P} / \mathrm{E}$ & $\mathrm{B}$ \\
\hline 7 & Source water protection & & $\sqrt{ }$ & & $\sqrt{ }$ & 4.8 & PS & $\mathrm{P} / \mathrm{E}$ & B \\
\hline 8 & Electricity consumption & & & $\sqrt{ }$ & & 0.2 & I & $\mathrm{O} / \mathrm{M}$ & $\mathrm{C}$ \\
\hline 9 & Number of employee & & $\sqrt{ }$ & & & 0.2 & I & $\mathrm{P} / \mathrm{E}$ & $\mathrm{C}$ \\
\hline 10 & Reliability of equipments & & $\sqrt{ }$ & & & 0.2 & PS & $\mathrm{O} / \mathrm{M}$ & $\mathrm{C}$ \\
\hline 11 & Maintenance of equipments & & $\sqrt{ }$ & & & 0.2 & PS & $\mathrm{O} / \mathrm{M}$ & $\mathrm{C}$ \\
\hline
\end{tabular}

${ }^{\mathrm{a}} \mathrm{Score}$ of survey $=$ summation the scores of items $\div$ number of retrieved questionnaire.

${ }^{\mathrm{b}} C=$ context $I=$ input; $\mathrm{PS}=$ process; and $\mathrm{PT}=$ product.

${ }^{\mathrm{c}} \mathrm{P} / \mathrm{E}=$ planning and engineering; and $\mathrm{O} / \mathrm{M}=$ operation and maintenance

${ }^{\mathrm{d}} \mathrm{A}=$ strongly recommended (for indicators with three " $\mathrm{v}$ " and scores of questionnaire survey above 4.0); B=recommended (for indicators with two " $"$ " and scores of questionnaire survey above 4.0); and $\mathrm{C}=$ not recommended (for indicators with less than two " $\rho$ " and scores of questionnaire survey below 4.0).

Table 2. Contents of Questionnaire for Soliciting Performance Indicators Department name

Solicit the significant or important performance indicators

(Hint: Give points from 5 to 1 depending upon its relative importance. Points 5: very important; Points 4: important; Points 3: fair; Points 2: less important; Point 1: not important)

1. Water quality control

2. In-plant modification and contingency plan

3. Water production rate

4. Chemical cost reduction

5. Equipment availability

6. Waste minimization

7. Source water protection

8. Electricity consumption

9. Number of employee

10. Reliability of equipments

11. Maintenance of equipments

Make comments and recommendations on needs of performance indicators

1. What are the workload, ability, moral, and loyalty of employees in your department?

2. What is your impression about "authorization" in your department?

3. What is your response or impression after the "outcome assessment"?

4. What is your correction plan if you cannot achieve your objective?

5. How does your business plan or annual budget affect your implementation plans?

6. What are your strategies or action plans to upgrade your company performance; please point out the most significant task force should be implementing.

\section{Establishment of Performance Evaluation System for Taipei Water Treatment Plant}

The performance evaluation system initially developed for the water production department was then used for the Taipei water treatment plant (Fig. 1). According to the CPE classification, the performance indicators recommended for the water production department were reorganized and categorized as follows: in-plant modification and contingency plan, chemical cost reduction, and source water protection (CPE management, shown in Table 4); equipment availability (CPE maintenance, shown in Table 5); and water quality control, water production rate, and waste minimization (CPE operation, shown in Table 6). In the following, the detailed evaluation items for each performance indicator were determined through integration of the performance evaluation system for the water production department and the CPE technique so that the performance evaluation system for the Taipei water treatment plant was established. This information should be useful and applicable to all water treatment plants in Taiwan.

\section{Development of Implementation Plan for Upgrading Performance of Taipei Water Treatment Plant}

This section will focus on an implementation plan for upgrading the performance of the Taipei Water Treatment Plant. The planning tasks include problem identification, goal analysis, and strategy formulation.

Issue identification includes analysis of external environmental factors and analysis of internal factors. Detailed discussions are provided below.

\section{Issue Identification}

The external environmental factors affecting the operational management of Taipei water treatment plant include the following:

1. Public demand: The improvement of living standards in Taipei areas in the past several decades has resulted in public demand for high-quality water. Therefore, maintaining high- 
Table 3. Major Evaluation Items and Corresponding Weight for Performance Indicators in Production Department of Taipei Water Company

\begin{tabular}{|c|c|c|}
\hline Performance indicator & Major evaluation items & $\begin{array}{c}\text { Weight } \\
(\%)\end{array}$ \\
\hline \multirow[t]{3}{*}{ Water quality control $(15 \%)$} & Process control & 40 \\
\hline & Laboratory capability & 20 \\
\hline & Data management & 40 \\
\hline \multirow[t]{3}{*}{ In-plant modification and contingency plan (15\%) } & Treatability evaluation & 30 \\
\hline & Preventive maintenance & 40 \\
\hline & Administration capability & 30 \\
\hline \multirow[t]{2}{*}{ Water production $(10 \%)$} & Calibration of flow meter & 80 \\
\hline & Measurement of water flow & 20 \\
\hline \multirow[t]{2}{*}{ Chemical cost reduction (10\%) } & Statistical analysis of operation and maintenance cost & 60 \\
\hline & Cost-benefit analysis & 40 \\
\hline \multirow[t]{2}{*}{ Equipment availability $(10 \%)$} & Maintenance program & 40 \\
\hline & Maintenance resources & 60 \\
\hline \multirow[t]{2}{*}{ Waste minimization $(10 \%)$} & Evaluation of sludge management system & 50 \\
\hline & Implementation of pollution prevention program & 50 \\
\hline \multirow{6}{*}{ Source water protection $(30 \%)$} & Establishment of water quality standard and its regulations & 15 \\
\hline & Level of compliance with source water quality standard & 10 \\
\hline & Investigation and statistic of polluted source & 10 \\
\hline & Environmental protection & 20 \\
\hline & Emergency response plan & 15 \\
\hline & Inspection and auditing program & 30 \\
\hline
\end{tabular}

quality drinking water is an essential goal of the Taipei water treatment plant.

2. Present and potential market competitors: Bottled water is becoming popular in Taiwan due to reasonable price and convenience. Besides bottled water, desalination technology is also an option for the public as well as for industries in selecting alternate sources of drinking water.

3. Stability of source water quality: Maintaining stable source water quality is the most important external environmental factor. The important factors affecting the source water quality were as follows: (1) eutrophication; (2) high turbidity during storms; and (3) pollution due to discharge of toxic substances. Source water protection to achieve good quality of raw water should be a higher priority than improvement of treatment processes to achieve better finished water quality when source water quality is poor. Achieving good quality of source water requires the cooperation of citizens and government. Public awareness of ecology and the importance of source water protection are essential in achieving the source water protection goals.

Internal factors affecting the operational management of the Taipei water treatment plant include the following items:

1. Limiting factors from CPE: According to the comprehensive performance evaluation of the Taipei water treatment plant, except for the filtration process, the capacities of all treatment processes are designed adequately. However, improvement must be made in operation for these processes. A CPE conducted at the Taipei water treatment plant in 2001 showed problems regarding the design, operation, and maintenance of the plant. Analysis found fifteen (15) minor limiting factors, which are summarized in Table 7 (Chen et al. 2002).

2. Lack of young professionals: The service year span of all employees in the water plant indicates that approximately $68 \%$ of the employees have been there for more than 15 years. This means that most of the employees have good experience in plant operation and emergency response. However, a lack of young employees with modern skills to develop innovative technologies or integrated management systems can be a drawback. It is, therefore, recommended that employees have intensive education and training programs particularly in the area of information technology.

Results from the issue identification will be used as a backbone in formulating a feasible management strategy.

The most important operational management goal for the Taipei water treatment plant is to maintain good water quality regardless of variations in raw water quality. The operational management goals are excellent source water quality, adequate water quantity, and excellent finished water quality.

\section{Optimization of Performance}

In our previous paper (Chang et al. 2005), it was reported that the total coliforms, total organic carbon (TOC), and chemical oxygen demand (COD) were selected as the major parameters because of their specific characteristics associated with the disinfection efficiency and disinfection by-products formation and in compliance with source water quality in Taiwan. Since all the major water quality parameters, i.e., TOC, $\mathrm{COD}, \mathrm{NH}_{3}-\mathrm{N}$, total coliforms, $\mathrm{As}, \mathrm{Pb}, \mathrm{Cd}, \mathrm{Cr}, \mathrm{Hg}$, and $\mathrm{Se}$ can meet the source water quality standards, these parameters can be easily treated to achieve the drinking water quality standards in this selected water treatment plant. However, the turbidity affected the quality and quantity of the water supply system and became the local environmental issue, especially during the typhoon periods. Therefore, the turbidity would be selected as the major factor for performance evaluation in this research work.

In order to optimize the performance of the Taipei water treatment plant, two objective functions (water production cost and removal efficiency) incorporated with four performance indicators (water quality control, water production rate, chemical cost reduction, and waste minimization) are integrated to develop 12 mathematical equations in this research to simulate the perfor- 
Table 4. Performance Indicators Categorized as Comprehensive Performance Evaluation Management and Their Detailed Evaluation Items Suggested by Comprehensive Performance Evaluation Practice

\begin{tabular}{|c|c|c|c|c|}
\hline $\begin{array}{l}\text { Performance } \\
\text { indicator }\end{array}$ & $\begin{array}{l}\text { Weight } \\
(\%)\end{array}$ & \multicolumn{3}{|c|}{ Evaluation items } \\
\hline \multirow{19}{*}{$\begin{array}{l}\text { In-plant modification } \\
\text { and contingency } \\
\text { plan }(15 \%)\end{array}$} & 30 & Treatability evaluation & \multirow{3}{*}{\multicolumn{2}{|c|}{$\begin{array}{l}\text { - Set performance objectives for each unit process } \\
\text { - Treated water quality in compliance with drinking water quality standards } \\
\text { - Documentation of SOP (standard operation procedure) }\end{array}$}} \\
\hline & & & & \\
\hline & & & & \\
\hline & 40 & Preventive maintenance & \multicolumn{2}{|c|}{ Implementation of the operation and maintenance manual } \\
\hline & & & \multirow[t]{6}{*}{$\begin{array}{l}\text { Unit process maintenance } \\
\text { and emergency response }\end{array}$} & $\begin{array}{l}\text { 1. The adequate chemical storage to handle the issues } \\
\text { happening during the transportation }\end{array}$ \\
\hline & & & & $\begin{array}{l}\text { 2. A replacement plan for breakdown of chemical addition } \\
\text { facilities }\end{array}$ \\
\hline & & & & 3. A warning system for hazardous chemicals release \\
\hline & & & & $\begin{array}{l}\text { 4. The adequate spare parts prepared for the unexpected } \\
\text { accidents }\end{array}$ \\
\hline & & & & $\begin{array}{l}\text { 5. The backup system can fix the situation rapidly when } \\
\text { the major system has a breakdown }\end{array}$ \\
\hline & \multirow{10}{*}{30} & & & 6. Sufficient on-site maintenance capacities \\
\hline & & \multirow[t]{9}{*}{ Administration capability } & \multirow[t]{5}{*}{ Characters of operators } & 1. Attempt to achieve the objective \\
\hline & & & & $\begin{array}{l}\text { 2. Willingness to be responsible for upgrading the } \\
\text { performance of water treatment plant }\end{array}$ \\
\hline & & & & 3. Enthusiasm for learning \\
\hline & & & & 4. Confidence and ability in changes of treatment schemes \\
\hline & & & & 5. Assist changes of treatment and whom to contact \\
\hline & & & \multirow[t]{4}{*}{ Contingency plans: response } & $\begin{array}{l}\text { 1. Notification, direction, and control, including purpose, } \\
\text { responsibilities, control center, and emergency activation }\end{array}$ \\
\hline & & & & $\begin{array}{l}\text { 2. Procedures, including order of priority and other } \\
\text { provisions }\end{array}$ \\
\hline & & & & $\begin{array}{l}\text { 3. Evacuation and personnel accountability, including } \\
\text { evacuation procedures and evacuation head count } \\
\text { procedures }\end{array}$ \\
\hline & & & & $\begin{array}{l}\text { 4. Emergency public information, including purpose, } \\
\text { responsibility, press center, press release and media } \\
\text { guidelines (Hathaway 2000) }\end{array}$ \\
\hline \multirow[t]{6}{*}{$\begin{array}{l}\text { Source water protection } \\
(30 \%)\end{array}$} & 15 & \multicolumn{3}{|c|}{$\begin{array}{l}\text { Establishment of water quality } \\
\text { standard and its regulations }\end{array}$} \\
\hline & 10 & \multicolumn{3}{|c|}{$\begin{array}{l}\text { Degree of compliance with source } \\
\text { water quality standard }\end{array}$} \\
\hline & 10 & \multicolumn{3}{|l|}{ Sources inventory } \\
\hline & 20 & \multicolumn{3}{|l|}{ Environmental conservation } \\
\hline & 15 & \multicolumn{3}{|l|}{ Emergency response plan } \\
\hline & 30 & \multicolumn{3}{|c|}{ Inspection and auditing program } \\
\hline
\end{tabular}

mance of the Taipei water treatment plant with different operation parameters. We also propose the strategies on reducing sediment and turbidity in raw water for source water protection. The developed equations and parameters based on the available data from the Taipei water treatment plant are summarized in Table 8.

The first objective function is water production cost [Eq. (1) in Table 8], which is made up by the cost of coagulation [use (PAC) as coagulant], cost of disinfection (use chlorine as disinfectant), cost of electricity, and cost of sludge management [Eqs. (3), (6), (8), and (10) in Table 8]. The cost of each component is calculated by the product of the unit cost and the amount of consumption. The second objective function is removal efficiency [Eq. (2) in Table 8], which is related to the amount of PAC addition $\left(\mathrm{PAC}^{\prime}\right)$, surface flow rate of grit chamber $\left(\mathrm{SOR}_{p}\right)$, surface flow rate of sedimentation tank $\left(\mathrm{SOR}_{s}\right)$, and filtration rate of rapid filtration tank (FR). The basic equations [Eqs. (1)-(3), (6), (8), and (10)] presented in Table 8 were originally developed by $\mathrm{Wu}$ (1986), and modified and validated by the available water quality data and operational data of each treatment unit gathered from 1998 to 2000 in this research. Consequently, these developed equations can be used to simulate the operating conditions in the Taipei water treatment plant to enable development of an implementation plan to optimize the performance of the plant.

The cost of coagulation is related to PAC dosage [Eqs. (4) and (5)], which is a function of turbidity in source water obtained from the results of jar tests. The experimental data are fairly consistent with the results predicted by Eq. (4) shown in Fig. 4. The cost of disinfection is related to chlorine consumption [Eq. (7)]. The cost of electricity is composed of electricity consumption of rapid filtration, coagulation, and sludge pumping [Eq. (9)]. The cost of sludge management in terms of source water turbidity, PAC addition, and water content is calculated as Eq. (11).

Nonlinear regression analysis was used to determine the parameters in objective function of removal efficiency [Eq. (2)] and the results are presented in Eq. (12). 


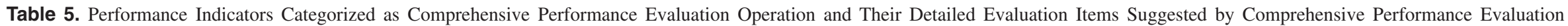
Practice

\begin{tabular}{|c|c|c|c|c|}
\hline $\begin{array}{l}\text { Performance } \\
\text { indicator }\end{array}$ & $\begin{array}{l}\text { Weight } \\
(\%)\end{array}$ & & & Evaluation items \\
\hline \multirow{25}{*}{$\begin{array}{l}\text { Water } \\
\text { quality } \\
\text { control } \\
(15 \%)\end{array}$} & \multirow[t]{17}{*}{40} & \multirow{17}{*}{$\begin{array}{l}\text { Process } \\
\text { control }\end{array}$} & \multirow[t]{3}{*}{ Coagulation/softening } & 1. Chemicals used/feed location \\
\hline & & & & 2. Does control (adjustment for flow changes; adjustment for water quality) \\
\hline & & & & 3. Monitoring (turbidity, particle counting) \\
\hline & & & \multirow[t]{4}{*}{ Flocculation } & 1. Mixing energy adjustment \\
\hline & & & & 2. Use of flocculant aid \\
\hline & & & & 3. Monitoring \\
\hline & & & & 4. Operational problems \\
\hline & & & \multirow[t]{3}{*}{ Sedimentation } & 1. Performance objective/monitoring (turbidity) \\
\hline & & & & 2. Sludge removal (control, adjustment) \\
\hline & & & & 3. Operational problems \\
\hline & & & \multirow[t]{5}{*}{ Filtration } & 1. Performance objective/monitoring (turbidity, particles, headloss, runtime) \\
\hline & & & & 2. Rate control due to demand, filter backwash \\
\hline & & & & 3. Basis for backwash initiation \\
\hline & & & & 4. Backwash procedures \\
\hline & & & & 5. Filter/media inspections \\
\hline & & & \multirow[t]{2}{*}{ Disinfection } & 1. Performance objective/monitoring (residual, CT) \\
\hline & & & & 2. $\mathrm{CT}$ factors (pH, minimum depth pf contactor, maximum residual) \\
\hline & \multirow[t]{5}{*}{20} & \multirow{5}{*}{$\begin{array}{l}\text { Laboratory } \\
\text { capability }\end{array}$} & \multicolumn{2}{|l|}{ - Sampling frequency } \\
\hline & & & \multirow{2}{*}{\multicolumn{2}{|c|}{$\begin{array}{l}\text { - Sampling items } \\
\text { - Samples labeling }\end{array}$}} \\
\hline & & & & \\
\hline & & & \multicolumn{2}{|c|}{ - Describe available analytical capability } \\
\hline & & & \multicolumn{2}{|c|}{ - Describe laboratory space/equipment and procedures } \\
\hline & 40 & Data & \multicolumn{2}{|l|}{ - Data collection } \\
\hline & & management & \multicolumn{2}{|l|}{ - Data application } \\
\hline & & & \multicolumn{2}{|c|}{ - Tracking and management procedures for monitoring data } \\
\hline \multirow{9}{*}{$\begin{array}{l}\text { Chemical } \\
\text { cost } \\
\text { reduction } \\
(10 \%)\end{array}$} & \multirow[t]{9}{*}{60} & \multirow{9}{*}{$\begin{array}{l}\text { Operation and } \\
\text { maintenance cost }\end{array}$} & \multicolumn{2}{|l|}{ 1. Personnel expense } \\
\hline & & & \multicolumn{2}{|c|}{ 2. Cost of energy consumption (electricity consumption) } \\
\hline & & & \multicolumn{2}{|l|}{ 3. Cost of utilities } \\
\hline & & & \multicolumn{2}{|l|}{ 4. Cost of supplies } \\
\hline & & & \multicolumn{2}{|l|}{ 5. Cost of training } \\
\hline & & & \multicolumn{2}{|l|}{ 6. Cost of transportation } \\
\hline & & & \multicolumn{2}{|l|}{ 7. Cost of insurance } \\
\hline & & & \multicolumn{2}{|c|}{ 8. Cost of treatment chemicals } \\
\hline & & & \multicolumn{2}{|c|}{ 9. Cost of sludge treatment } \\
\hline
\end{tabular}

40 Cost-benefit analysis 
Table 5. (Continued.)

Performance Weight

indicator $\quad(\%)$

Water

production

Measurement

(10\%)

of water flow

(2)

80 Calibration of flow meters

Waste

minimization

$(10 \%)$
50 Evaluation of sludge management system

50 Implementation of pollution prevention program

\section{Evaluation items}

Historical water production 1. Flow during operation

data

Water usage

1. Determine the water usage per capita based on water production records and population served

2. Determine unaccounted for water based on monthly or annual water production and meter records.

3. Determine backwash water percent based in volume of water filtered and volume of water used for backwash

- Calibrated by the instruments

- Checked by pump efficiency

- Comparisons of measurement by the Parshall Flume

The amount of sludge 1. Ratio between the amount of sludge production and turbidity removal rates produced from each unit

$\begin{array}{ll}\text { process checked by the process } & \text { 2. Ratio between the amount of sludge production and wastewater discharge }\end{array}$

balance practices

Dewatering efficiency for sludge treatment processes

- The statement pf support from management by expressing the goals and objectives

- Understanding processes and wastes by gathering background information, defining/characterizing unit process, and performing material

balance

- Employee awareness and involvement through an intensive education and training program

- Reduction of treatment/disposal unit

- Reduction of safety hazards

- Improvement of on product quality

- Reduction in waste quantity

- Reduction of liability 
Table 6. Performance Indicators Categorized as Comprehensive Performance Evaluation Maintenance and Their Detailed Evaluation Items Suggested by Comprehensive Performance Evaluation Practice

\begin{tabular}{|c|c|c|c|}
\hline $\begin{array}{l}\text { Performance } \\
\text { indicator }\end{array}$ & $\begin{array}{l}\text { Weight } \\
(\%)\end{array}$ & & Evaluation Items \\
\hline \multirow[t]{2}{*}{$\begin{array}{l}\text { Equipment } \\
\text { availability } \\
(10 \%)\end{array}$} & 40 & $\begin{array}{c}\text { Maintenance } \\
\text { program }\end{array}$ & $\begin{array}{l}\text { - Preventive maintenance } \\
\text { - Corrective maintenance } \\
\text { - Predictive maintenance } \\
\text { - Housekeeping }\end{array}$ \\
\hline & 60 & $\begin{array}{l}\text { Maintenance } \\
\text { resources }\end{array}$ & $\begin{array}{l}\text { - Equipment repair and parts } \\
\text { - Maintenance expertise } \\
\text { - Work space and tools }\end{array}$ \\
\hline \multicolumn{2}{|c|}{$T_{r}^{\prime}=\frac{T_{i}-T_{e}}{T_{i}}=$} & \multicolumn{2}{|c|}{$143.4 \times \mathrm{PAC}^{1.99}+998600$} \\
\hline
\end{tabular}

The average error between the observed data and the simulated results shown in Fig. 5 is $5.1 \%$, which indicates that this equation can be introduced to estimate the removal efficiency of turbidity in source water by the water treatment plant.

By integrating the data of turbidity and water production rate in the Taipei water treatment plant into Eqs. (4), (5), (7), (9), and (11), the relationships among turbidity in source water, water production rate, and four categories of cost including coagulation, disinfection, electricity, and sludge management were disclosed. As shown in Figs. 6 and 7, it is obvious that the total treatment cost increases with increasing water production rate and the turbidity in source water. The higher the turbidity in the source water, the greater the cost of coagulation and sludge management, especially for the case of turbidity greater than 710 NTU. On the other hand, the cost of electricity and disinfection are not greatly influenced by turbidity in the source water. As for the increase of water production rate, the cost of the above-mentioned four categories will all increase.

\section{Implementation Plans}

Afterward, two suggestions are made for the Taipei water treatment plant. First of all, lower the water production rate for high turbidity in source water and heighten the water production rate for low turbidity in source water for the maintenance of total treatment cost. Second, establish a manual of optimal operation parameters. Proper adjustment of the water production rate, PAC dosage, and sludge management for different turbidities in source water based on the required finished water quality can minimize the total treatment cost and optimize the performance of the water treatment plant.

In order to put the simulation results into application and solve the performance limiting factors (shown in Table 8) at the same time so as to upgrade the performance of the Taipei water treatment plant, the general principles are suggested as follows, according to the previously suggested performance indicators (shown in Tables 4-6):

1. Establishing a regular performance evaluation system to realize the potential and existing problems so that corrective action can be immediately taken;

2. Evaluating the overall performance of the water treatment plant by the technical committee so that suggestions to the plant manager can be made objectively;

3. Building up partnerships with other water treatment plants and exchanging technology experiences frequently;
Table 7. Performance Limiting Factors for Taipei Water Treatment Plant

\begin{tabular}{|c|c|}
\hline Category $^{\mathrm{a}}$ & Performance limiting factor \\
\hline \multirow[t]{10}{*}{$\mathrm{B}$} & $\begin{array}{l}\text { 1. Filters are in poor condition due to long term } \\
\text { overloading }\end{array}$ \\
\hline & 2. Unevenly post chlorination \\
\hline & $\begin{array}{l}\text { 3. The effect of surface wash is not sufficiently good } \\
\text { due to clogged nozzles }\end{array}$ \\
\hline & $\begin{array}{l}\text { 4. Concavity on the surface of filter media boils and } \\
\text { uneven distribution of water occurs during backwash }\end{array}$ \\
\hline & 5. Dosing pipes are clogged frequently \\
\hline & 6. Some flash mixers are not in good condition \\
\hline & 7. Part of included tubes are broken and clogged \\
\hline & $\begin{array}{l}\text { 8. Unevenly inflow, due to improper inlet water } \\
\text { elevation }\end{array}$ \\
\hline & $\begin{array}{l}\text { 9. Basin inlet gates are not reliably controlled. Hence, } \\
\text { flow splitting and effect of flocculation are not even }\end{array}$ \\
\hline & $\begin{array}{l}\text { 10. Some broken inclined tubes and improper overflow } \\
\text { weirs }\end{array}$ \\
\hline \multirow[t]{5}{*}{$\mathrm{C}$} & $\begin{array}{l}\text { 1. The time of cleaning is not easy to schedule } \\
\text { according to the build-up volume of settled sludge }\end{array}$ \\
\hline & $\begin{array}{l}\text { 2. The new database and dosing cures are still in } \\
\text { construction }\end{array}$ \\
\hline & $\begin{array}{l}\text { 3. Backwash water is recycled to process, not to be } \\
\text { dewatered }\end{array}$ \\
\hline & 4. Confusions about right power in temporal team \\
\hline & 5. Plant must be operated limited by minimum flow $r$ \\
\hline
\end{tabular}

${ }^{\mathrm{a}} \mathrm{CPE}$ classification system for prioritizing performance limiting factors to three categories: $\mathrm{A}=$ major effect on a long-term, repetitive basis; $\mathrm{B}=$ minor effect on a routine basis or major effect on a periodic basis; and $\mathrm{C}=$ minor effect.

4. Developing a sound database to provide a scientific approach for optimizing the performance of the water treatment plant; and

5. Proposing a strategic plan for cooperating with stakeholders for source water protection.

The first recommended strategic plan is to complete and execute a source water protection plan for the Taipei water treatment plant. It was mentioned in the previous section that maintaining stable source water quality is the most important external environmental factor affecting the operational management of the plant. Therefore, protecting the source water of the Taipei water treatment plant by implementing the National Policy is the first task to be carried out. The National Policy should include (1) soil conservation policies in reducing soil erosion and sediment in the reservoir, (2) evaluation and development of appropriate soil conservation practices, best management practices (BMP) in reducing sediment in the reservoir, and (3) determination of the sediment sources by using the TMDL (total maximum daily load) approaches to assign sediment load allocation to each tributary of the reservoir.

In the past decade, pollution control in Taiwan focused on point source management. However, nonpoint source pollution control is currently receiving much attention. Policies regarding TMDL and BMPs are currently being drafted by the Taiwan Environmental Protection Administration (TEPA) to minimize nonpoint source pollution. TMDL is a water quality base strategic plan to minimize pollutant load to a watershed. Data for determining TMDL include background water quality data, hydrologic data of a watershed, locations of point and nonpoint sources, and characteristics of pollutants (USEPA 1999). The Taipei water 
Table 8. Objective Functions for Taipei Water Treatment Plant

Objective functions

Economic objective:

$Z=\frac{(\mathrm{CP}+\mathrm{CL}+\mathrm{CE}+\mathrm{CS})}{Q}$

Eq. (1)

Effective objective:

$T_{r}^{\prime}=\frac{T_{i}-T_{e}}{T_{i}}=\frac{a \times \mathrm{PAC}^{\prime m}+c_{1}^{\prime}}{b \times \mathrm{SOR}_{p} \times \mathrm{SOR}_{s} \times \mathrm{FR}+c_{2}^{\prime}}$

Eq. (2)
Components of functions

Cost of coagulation:

$$
\begin{gathered}
\mathrm{CP}=p \times \mathrm{PAC}^{\prime} \\
p=2.7
\end{gathered}
$$

$\mathrm{PAC}(\mathrm{ppm})=3.236 \times T_{i}^{0.42}$

Eq. (3)

Eq. (4)

$\mathrm{PAC}^{\prime}(\mathrm{Kg} /$ day $)=3.236 \times T_{i}^{0.42} \times Q \times 10^{-3}$

Cost of disinfection:

$$
\begin{gathered}
\mathrm{CL}=c \times \mathrm{Cl} \\
c=9.1
\end{gathered}
$$$$
\mathrm{CL}=1.1 \times Q \times 10^{-3}
$$

Cost of electricity:

$$
\mathrm{CE}=e \times \mathrm{E}
$$$$
e=2.95
$$

$$
E=E_{\mathrm{fo}}+E_{\mathrm{fl}}+E_{w}=4.21 \times 10^{-3} Q+28850
$$

Cost of sludge management:

$$
\mathrm{CS}=s \times \mathrm{SL}
$$$$
s=1.8
$$

$$
\mathrm{SL}=\left(T_{i} \times 10^{-6} \times Q+\mathrm{PAC}^{\prime} \times 0.157 \div 0.45\right)
$$

water contained: $45 \%$

Suggested values:

$$
a=143.41
$$

$b=1.77 \times 10^{-3}$

$c_{1}^{\prime}=998599.4$

$c_{2}^{\prime}=925287.4$

$m=1.99$

$\mathrm{SOR}_{p}:$ 1728-6048 m/day

$\mathrm{SOR}_{s}: 58-147 \mathrm{~m} /$ day

FR: $100-300$ m/day treatment plant should cooperate with the TEPA to execute the TMDL plan by identifying problems, establishing water quality goals, investigating pollution sources, evaluating the relationship between water quality criteria and pollution sources, distributing pollutant loads, establishing monitoring and followup plans, and finalizing TMDL and integration.

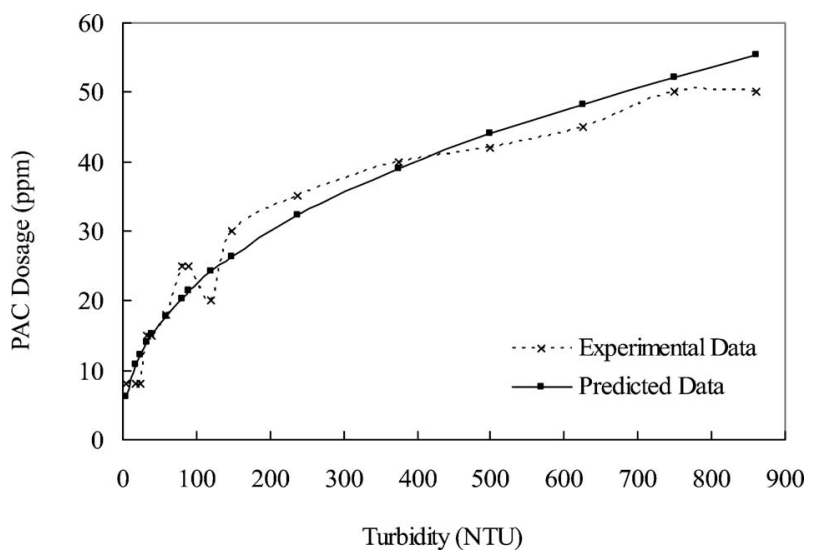

Fig. 4. Relationship between experimental data and predicted data of PAC dosage with respect to turbidity at Taipei water treatment plant

\section{Conclusions}

Performance evaluation systems for the water production department in the Taipei Water Company and Taipei water treatment plant were developed throughout this investigation. By reviewing and screening the literatures, discussion in the forums and analyzing the results of questionnaire survey, seven performance indicators (water quality control, in-plant modification and con-

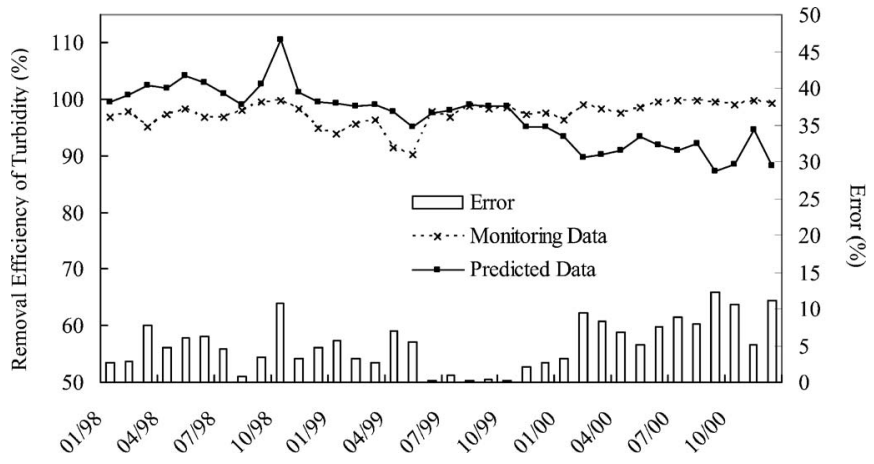

Fig. 5. Relationship between monitoring data and predicted data of turbidity removal efficiency at Taipei water treatment plant 


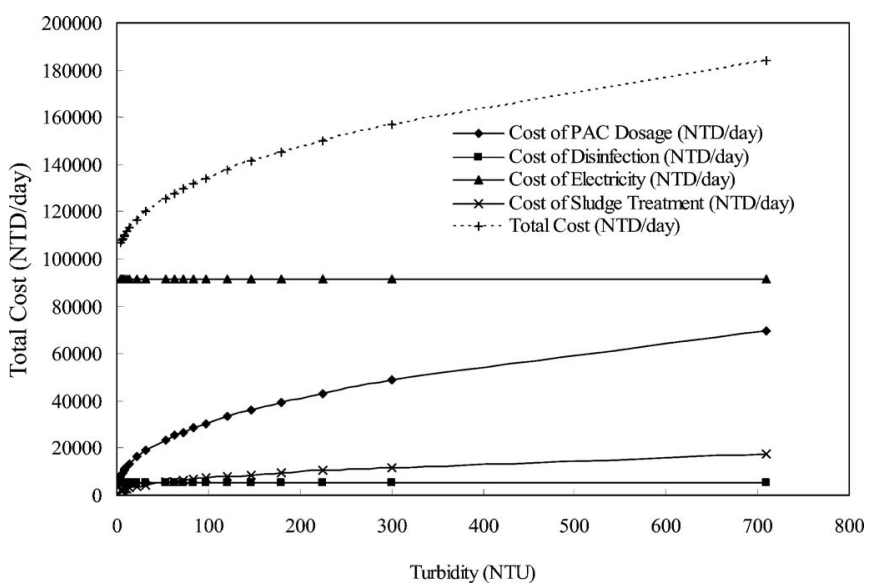

Fig. 6. Relationship between components of cost and turbidity in source water

tingency plan, water production rate, chemical cost reduction, equipment availability, waste minimization, and source water protection) as well as their major evaluation items were proposed to the water production department. Then the selected performance indicators were analyzed by the AHP method with the expert choice software to determine the relative weight value of each performance indicator and their major evaluation items.

According to the CPE practice, the performance evaluation system initially developed for the water production department can be categorized into management, maintenance, and operation areas and then used for the Taipei water treatment plant with the determination of detailed evaluation items for each performance indicator. This very unique experience could be transferred to other water treatment plants in Taiwan.

Through a series review by the CPE practice at the Taipei water treatment plant, external problems and internal performance-limiting factors were discovered. In order to achieve the goals of excellent source water quality, adequate water quality, and excellent finished water quality, two objective functions (water production cost and removal efficiency) are developed and analyzed to draw out an implementation plan for optimizing the performance of the Taipei water treatment plant. Proper adjustment of the water production rate, PAC dosage, and sludge

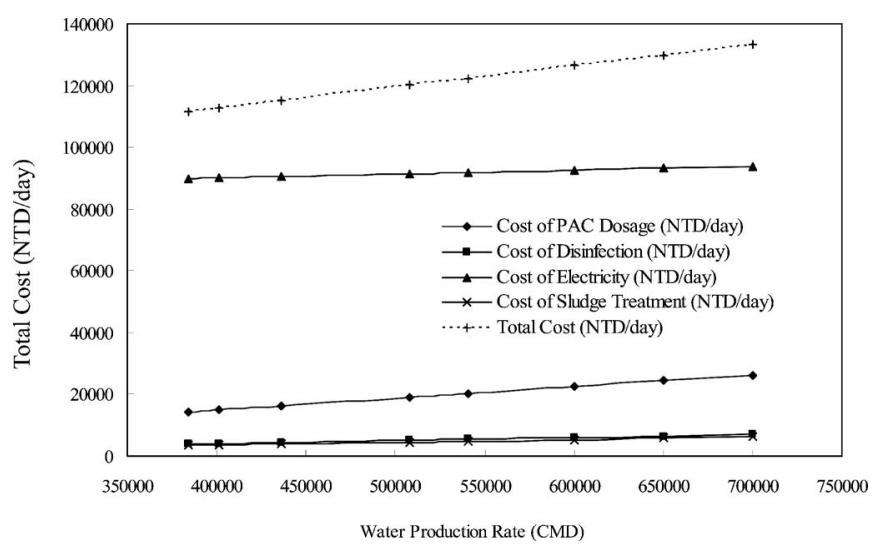

Fig. 7. Relationship between components of cost and water production rate management for different turbidities in source water based on the required finished water quality can minimize the total treatment cost and enhance the performance of the water treatment plant. In addition, establishing a regular performance evaluation system to identify potential and existing problems so that correction action could be immediately taken, developing a sound database program, and cooperating with the stakeholders for source water protection are the major tasks that should be implemented to achieve the objectives of safe drinking water and clean water.

\section{Notation}

The following symbols are used in this paper:

$a=$ parameter of Eq. (11);

$b=$ parameter of Eq. (11);

$c=$ cost of unit disinfectant (kg/NTD);

$c_{1}^{\prime}=$ parameter of Eq. (11);

$c_{2}^{\prime}=$ parameter of Eq. (11)

$\mathrm{CE}=$ cost of electricity (NTD/day);

$\mathrm{Cl}=$ addition of disinfectant ( $\mathrm{kg} /$ day $)$;

$\mathrm{CL}=$ cost of disinfection (NTD/day);

$\mathrm{CP}=$ cost of coagulation (NTD/day);

$\mathrm{CS}=$ cost of sludge management (NTD/day);

$e=$ cost of unit electricity $(\mathrm{NTD} / \mathrm{kW} / \mathrm{h})$;

$E=$ electricity consumption of equipment $(\mathrm{kW} / \mathrm{h} /$ day $)$;

$E_{\mathrm{fl}}=$ electricity consumption of rapid filtration tank (kW/h/day);

$E_{\mathrm{fo}}=$ electricity consumption of coagulation tank (kW/h/day);

$E_{\mathrm{w}}=$ electricity consumption of sludge pumping $(\mathrm{kW} / \mathrm{h} /$ day $)$;

$\mathrm{FR}=$ filtration rate of rapid filtration tank $(\mathrm{m} /$ day $)$;

$m=$ parameter of Eq. (11);

$p=$ cost of unit coagulant $(\mathrm{kg} / \mathrm{NTD})$;

$\mathrm{PAC}=$ addition of PAC $(\mathrm{ppm})$;

$\mathrm{PAC}^{\prime}=$ addition of PAC ( $\mathrm{kg} /$ day $)$;

$Q=$ water production rate $\left(\mathrm{m}^{3} /\right.$ day $)$;

$s=$ cost of unit sludge management $(\mathrm{kg} / \mathrm{NTD}) ;$

$\mathrm{SL}=$ sludge production $(\mathrm{kg} /$ day $)$;

$\mathrm{SOR}_{p}=$ surface flow rate of grit chamber (m/day);

$\mathrm{SOR}_{s}=$ surface flow rate of sedimentation tank (m/day);

$T_{e}=$ turbidity in finished water (NTU);

$T_{i}=$ turbidity in source water (NTU);

$T_{r}^{\prime}=$ removal efficiency of turbidity $(\%)$; and

$Z=$ unit treatment cost (NTD/day).

\section{References}

Chang, E. E., Chiang, P. C., Lin, Y. L., and Tsai, H. P. (2005). "Evaluation of source water quality standards for total coliforms, TOC, and COD in Taiwan." Pract. Period. Hazard. Toxic Radioact. Waste Manage., 9(3), 193-203.

Chen, M. L., Fan, F. Y., Chen, C. C., and Shih, M. H. (2002). "An approach to optimizing the performance of ChihTan water purification plant of Taipei Water Department." 8th Int. Conf. on Drinking Water Quality Management and Treatment Technology, Kaohsiung, Taiwan.

Choi, S., Yun, Z., Yoon, J., Hong, J., and Lee, Y. (2002). "Performance evaluation program of water treatment plant in Korea." Water Sci. Technol.: Water Supply, 2(5-6), 143-148. 
Hathaway, R. A. (2000). "Contingency plans V: Response." Chem. Health Safety, 7(1), 10-14.

International City/County Management Association (ICMA). (1999). "Beyond data: Current uses of comparative performance measurement in local government." Washington, D.C.

Kaufman, R. (1988). "Preparing useful performance indicators." Training Development, 52(9), 80-83.

Paralez, L. L. (2001). "Performance assessment in US water and wastewater utilities." J. Am. Water Works Assoc., 93, 68-76.

Saaty, T. L. (1980). The analytic hierarchy process, McGraw-Hill, New York.
Taipei Water Department (TWD). (2000). Water supply of Taipei, Print Printing Co., Ltd., Taipei.

U.S. Environmental Protection Agency (USEPA). (1998). "Handbook: Optimizing water treatment plant performance using the composite correction program." EPA/625/6-91/027, Cincinnati.

U.S. Environmental Protection Agency (USEPA). (1999). "Draft guidance for water quality-based decisions: The TMDL process, 2nd Ed." EPA-841-D-99-001, Washington, D.C.

Wu, M. Y. (1986). "Optimization design of water treatment and its evaluation.” Ph.D. thesis, National Taiwan Univ., Taiwan, Republic of China. 